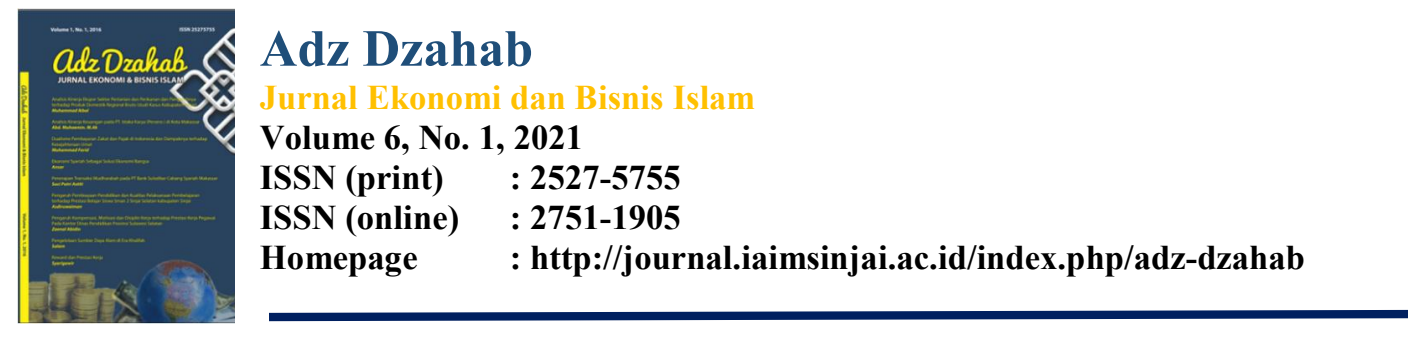

\title{
PENGARUH KOMPENSASI KINERJA GURU HONORER DI SD NEGERI 30 TONGKE-TONGKE KABUPATEN SINJAI
}

\author{
Muhammad Ikbal ${ }^{1}$, Samsinar $^{2}$, Miftahul Aulia ${ }^{3}$, Nurwahida ${ }^{4}$, Salfianur $^{5}$ \\ 1,2,3,4,5 IAIM Sinjai, Sultan Hasanauddin no 20, Sinjai \\ Korespondesi Penulis.E-mail:_eqbalahamd@gmail.com,Tlp:081354797465
}

\begin{abstract}
Abstrak
Penelitian ini bertujuan untuk mengetahui pengaruh kompensasi terhadap kinerja guru honorer di SD Negeri 30 Tongke-Tongke yang berjumlah 9 orang, kebutuhan guru yang sangat mendasar adalah kebutuhan kompensasi seberapa besar pengaruh kompensasi terhadap kinerja guru honorer apakah hal tersebut memiiki signifikan atau tidak, dan untuk membuktikan apakah kompensasi berpengaruh signifikan .Penelitian ini termasuk penelitian survey menggunakan pendekatan kuantitatif. Dalam penelitian ini sampel yang digunakan diambil dari populasi yaitu guru honorer. tehnik pengumpulan data yang digunakan yaitu angket terstruktur dan dokumen. Tehnik analisis datanya menggunakan analisis biaya dan analisis regresi. Hasil penelitian ini menunjukkan bahwa terdapat pengaruh kompensasi terhadap kinerjaguru. Berdasarkan hasil analisis regresi sederhana yang di lakukan melalui program SPSS 20. Standar nilai berpegaruh atau tidak yaitu sig0.005 < sig 0,05 sehingga diketahui bahwaNilait hitung sebesar4,072sedangkan nilai t tabel sebesar 2,364dengan taraf signifikan sebesar 0,005. Nilai t hitung 14,072 > t tabel 2,364, dan sig 0,005<sig 0,05. Selain itu didapatkan hasil $R=0,839$ atau 83,9\%, dan angka $R$ Square adalah 0,703 atau 70,3 $\%$ sedangkan sisanya 29,7\%. Hal ini menunjukkan bahwa 70,3\% kompensasi berpengaruh terhadap kinerja guru honorer di SD Negeri 30 Tongke-Tongke Kab. Sinjai dan sisanya sebesar 29,7\% dipengaruhi oleh sebab lain yang tidak diteliti.
\end{abstract}

Kata Kunci: Pengaruh Konpensasi, Guru Honorer 


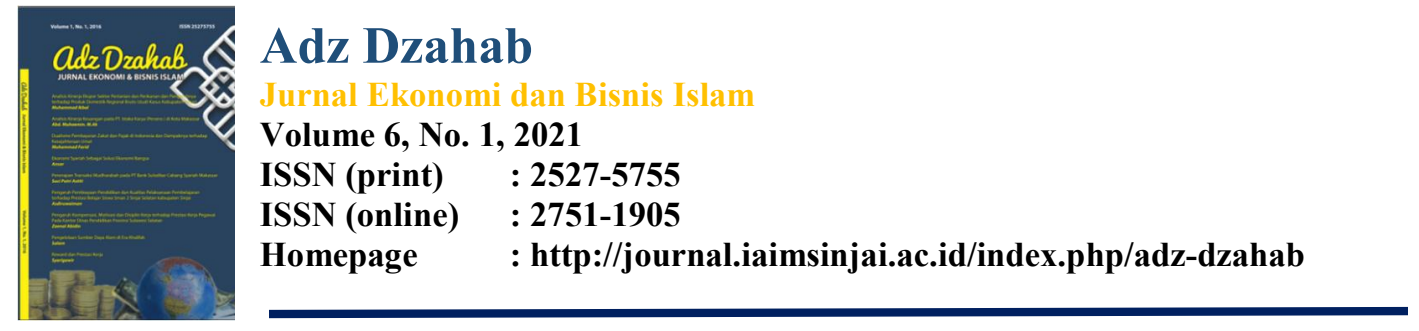

\section{Pendahuluan}

Pendidikan merupakan sebuah proses dengan metode-metode tertentu sehingga orang memperoleh pengetahuan, pemahaman, dan cara bertingkah laku yang sesuai dengan kebutuhan.Pendidikan tidak lepas dari peranan guru sebagai pengajar dan pendidik. Guru termasuk salah satu profesi yang berperan penting dalam membentuk sumber daya manusia yang berkualitas sehingga wajar jika dikatakan kalau guru menjadi ujung tombak dalam mencerdaskan kehidupan bangsa (Amos Nemos Neolaka, 2017:3). Guru tetap (PNS) dengan guru tidak tetap memiliki kesamaan kewajiban mengajar 24 jam dalam seminggu namun tingkat penghasilan mereka sangat berbeda. Tingkat kesejahteraan guru memang kurang mendapat perhatian dengan posisinya yang semakin marjianl dan masih sering kontrvensi. Bahwa gaji.yang diterima oleh guru juga dirasakan tidak sebanding dengan tanggung jawab yang mereka kerjakan (Dessy:2010).

Kinerja merupakan suatu kegiatan yang dilakukan untuk melaksanakan, menyelesaikan tugas dan tanggung jawab sesuai dengan harapan dan tujuan yang telah ditetapkan. Dilihat dari arti kata kinerja berasal dari kata performance.performance berarti prestasi atau pelaksanaan tugas. Dari pengertian tersebut kinerja di artikan sebagai prestasi, menunjukkan suatu kegiatan atau perbuatan dan melaksanakan tugas yang telah di bebankan. Pengertian kinerja sering didentikkan dengan prestasi kerja. Kinerjamengandung makna hasil kerja, kemampuan prestasiatau dorongan untuk melaksanakan suatu pekerjaa. Keberhasilan individu atau organisasi dalam mencapai target atau sasaran tersebut merupakan kinerja. Menurut Suprihanto,kinerjaadalah hasil keja seseorang dalam suatu priode tertetu yang dibandingkan dengan beberapa keungkina misalnya standar target, sasaran, atau ktiteria yang telah di tentukan terlebih dahulu.

Dalam hal ini, guru/pengajar/pendidik adalah pelanggan internal yang baik yang perlu diperhatikan agar puas dalam menyampaikan proses pembelajaran di kelas dan puas hasil yang dicapai siswa. Kualitas guru akan dicapai apabila dapat di penuhinya kebutuhankebutuhan yang diharapkan oleh guru. Kebutuhan guru yang sangat mendasar adalah kebutuhankompensasi, di mana kompensasi masih dirasakan belum memuaskan, dan itu sangat menentukan kinerja guru. menunjukkan bahwa ada kecenderungan negatif bahwa kompensasi tidak berpengaruh terhadap kinerja guru. Hal ini dapat dilihat dari wawancara dan pengamatan dilapangan yang penulis lakukan terhadap beberapa sekolah menunjukkan bahwa kinerja guru yang sudah mendapatkan kompensasi berupa tunjangan sertifikasi masih jauh dari yang diharapkan. Guru masih banyak yang tidak tepat waktu dalam mengajar, penyelesaian tugas yang dibebankan masih belum optimal.Sehingga berdasarkan uraian di atas penulis tertarik membahas penelitian yang berjudul "Pengaruh Kompensasi Terhadap Kinerja Guru Honorer".

\section{Metode}

\subsection{JenisPenelitian}

Jenis penelitian yang digunakan dalam penelitian ini adalah penelitian survei. Dalam metode survei ini sering digunakan instrumen kuesioner sebagai upaya pengumpulan data atau memperoleh informasi mengenai jumlah responden yang dianggap sebagai sampel yang mewakili populasi tertentu. Pelaksanaan survei dilakukan melalui proses pengumpuan informasi, fakta, dan analisis data sosial yang bersifat terstruktur serta mendetail melalui instrumen kuesioner atau daftar pertanyaan tertentu secara tesusun. Survei dilakukan melalui wawancara terstruktur dimana susunan pertanyaan-pertanyaan dalam bentuk kuesioner sudah disiapkan, termasuk pilihan jawabannya telah tersedia untuk diisi oleh responden.(Rosady Ruslan: 2015, 253).

\subsection{Pendekatan Penelitian}




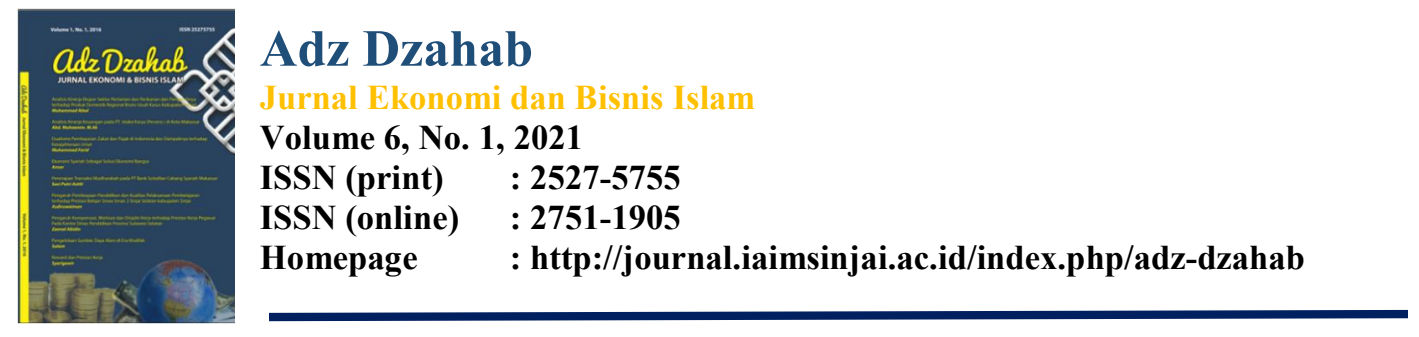

Pendekatan yang digunakan dalam penelitian ini adalah penelitian kuantitatif. Metode penelitian kuantitatif merupakan salah satu jenis penelitian yang dilakukan pada objek yang alamiah. Metode penelitian yang berdasarkan pada filsafat positivisme memandang penelitian pada umumnya dilakukan pada populasi atau sampel tertentu yang representatif. Untuk pengumpulan data digunakan instrumen penelitian. Data yang telah terkumpul selanjutnya dianalisis secara kuantitatif/statistik,dengan tujuan untuk menguji hipotesis terbukti atau tidak.(Sugiono, 2017:7)

1.1 Tekhnik pengumpulan data menggunkaan angket dan dokumentasi dokumentasi

1.2 Instrumen Penelitian

Instrumen penelitian aadalah alat atau fasillitas yang digunakan oleh peneliti dan pengumpulan data agar lebih mudah dan hasilnya baik, dalam artian lebih cermat, lengkap dan sistematis.

1.3 Tekhnik analisis data

1. Analisis data dokumentasi

2. Analisis data angket

\section{Hasil dan Pembahasan}

Kompensasi bagi para pekerja merupakan suatu tema yang sangat menarik untuk di bahas. Hal ini terjadi karena kompensasi memiliki keterkaitan yang sangat erat dengan kesejahteraan hidup para pekerja. Ketika banyak orang mendiskusikan kompensasi, sering kali mereka menyamakannya dengan gaji atau upah.

Kompensasi bagi para pengawai di bidang pendidikan merupaka topik yang harus di diskusikan dan diperbaiki secara terus-menerus oleh semua pihak. Hal ini karena selama ini, gaji yang diterima pada pendidik dan tenaga kependidikan di berbagai sekolah sering di bawah standar kerja. Di banyak sekolah, banyak guru dan pengawai yang tidak mendapatkan gaji yang layak. Walaupun sudah ada undang-undang yang menyebut bahwa guru sebagai profesi tidak otomatis gaji guru langsung dinaikkan. Banyak faktor yang harus dikaji terkait dengan penentuan gaji guru. Pada pendidikan persekolahan negeri, umumnya tidak terdapat hubungan.

fungsional antara biaya operasional lembaga dengan biaya yang harus dikeluarkan oleh masyarakat untuk pedidikan. Lembaga pendidikan negeri umumnya tidak langsung menanggung operasional pendidikan karena gaji tenaga pendidk sebagian besar di tanggung oleh pemerintah yang bersumber dari pajak yang dibayar oleh masyarakat. Sebaliknya. Pada lembaga pendidikan nonpemerintah (swasta), semua operasional pendidikan (termasuk gaji) di tanggung oleh biaya lembaga yang bersumber dari masyarakat penyandang dana Pendidikan memiliki tanggung jawab moral terhadap masyarakat selaku penanggung biaya Pendidikan melalui pembayaran pajak. Oleh relasi antara masyarakat dan pengelolah pendidikan menjadi transaksi ekonomi dalam bidang pendidikan. Transaksi ekonomi ini di pilah menjadi dua aspek, yaitu aspek. Pengelola sebagai produsen, dan aspek masyarakat sebagai konsumen. Produsen pendidikan terdiri atas pemerintah, pengelolah pendidikan, pendidik, dan masyarakat sebagai pengguna sekaligus mitra pendidikan. Sedangkan konsumen pendidikan terdiri atas masyarakat, orang tua, dan siswa. Kedua puhak tersebutterjadi transaksi timbal balik, walaupun secara tidak langsung, keduanya saling berpengaruh. Pajak masyarakat yang memadai untuk membayar gaji guru yang layak akan menghasilkan kinerja guru yang produktif, dan pada akhirnya dapat menghantarkan peserta didiknya menjdi lulusan yang diharapkan oleh masyarakat. 


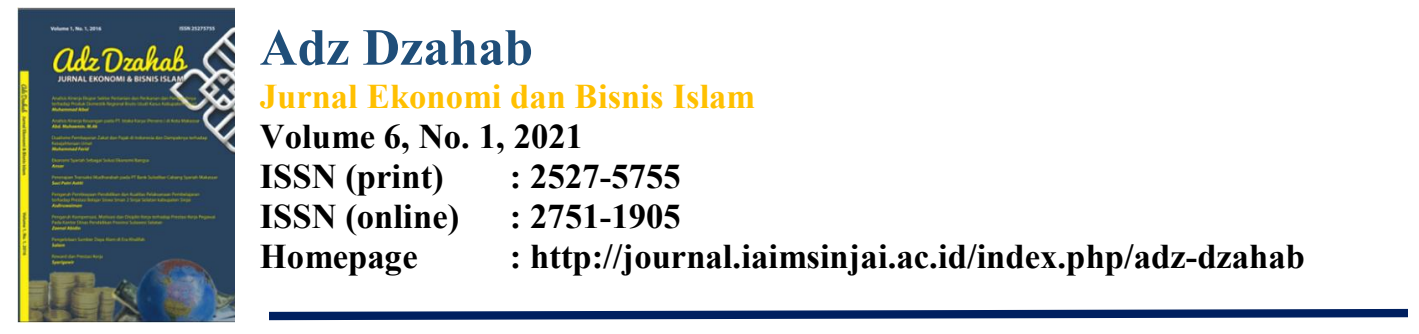

Pada dasarnya manusia salah satu sumberdaya yang bersifat dinamis dan memiliki kemampuan untuk terus berkembang dan juga ingin memperoleh uang untuk memenuhi kebutuhan hidupnya. Untuk itulah perlu mendapat perhatian dari pihak perusahaan. Perhatian ini diperlukan mengingat dalam menjalankan aktivitasnya, perusahaan akan selalu berhadapan dengan sumberdaya manusia yang dimilikinya. Dengan demikian pembinaanterhadap sumberdaya manusia perlu terus mendapatkan perhatian karena itulah perusaan memberikan penghargaan prestasi kerja karyawanan yaitu dengan jalan memberikan kompensasi. Untuk menarik, mempertahankan dan memotofasi karyawan. Salah satu cara menajemen untuk meningkatkan prestasi kerja, danmeningkatkan kinerjaparakaryawan adalah melalui kompensasi.

Kompensasi merupakan pengeluaran dan biaya bagi perusahaan. Perusahaan mengharapkan pengeluaran dan biaya kompensasi ini memperoleh imbalan prestasi kerja yang lebih besar dari karyawan supaya perusahaan tersebut mendapakan laba yang terjamin. Ada beberapa pendapat ahli tentang pengertian kompensasi yang dapat diberikan.

Kompensasi adalah semua bentuk upah atau imbalan yangberlaku bagi karyawan dan muncul dari pekerjaan mereka, dan mempunyai dua komponen. Ada pembayaran keuangan langsung dalam bentuk upah, gaji, insentif, komisi, dan bonus, dan ada pembayaran yang tidak langsung dalam bentuk tunjangan keuangan seperti uang asuransi dan uang liburan yang dibayarkan oleh majikan.

\section{A. Bentuk-Bentuk Kompensasi}

1) Kompensasi Langsung

Sampai saat ini pengertian kompensasi langsung masih mengunakan istilah administrasi gaji dan upah, adapun pengertian dari kompensasi secara terpisah kompensasi dengan pembayaran keuangan langsung dalam bentuk upah gaji, insentif, komisi dan bonus"kompensasi dibedakan menjadi dua macam yaitu: kompensasi langsung yang berupa gaji, upah, dan bonus. Dari penjelasan diatas kompensasi langsung merupakan bagian dari kompensasi secara keseluruan yang pembayaranya pada umumnya mengunakan uang, dan langsung terkait dengan dengan prestasi kerja yang dapat berbentuk gaji, upah, dan bonus. Adapun bentuk- bentuk kompensasi langsung adalah:

a. Gaji

Gaji adalah balas jasa dalam bentuk uang yang diterima karyawan sebagai konsekuensi dari kedudukanya sebagai seorang karyawan yang memberikan sumbangan tenaga dan pikiran dalam mencapai tujuan perusahaan. Dapat juga dikatakan sebagai bayaran tetap yang diterima seseorang dari keanggotaannya dalam sebuah perusahaan.

b. Upah

Upah merupakan imbalan financial langsung yang dibayarkan kepada karyawan berdasarkan jam kerja, jumlah barang yang dihasilkan atau banyaknya pelayanan yang diberikan. Jadi tidak seperti gaji yang jumlahnya relatif tetap, besarnya upah dapat berubah-ubah tergantung pada keluaran dan dihasilkan.

c. Bonus

Insentif merupakan imbalan langsung yang dibayarkan kepada karyawan karena kinerja melebihi standar yang ditentukan. Insentif merupakan bentuk lain dari upah langsung diluar upah dan gaji yang merupakan kompensasi tetap, yang biasa disebut kompensasi berdasarkan kinerja.

2) Kompensasi Tak Langsung 


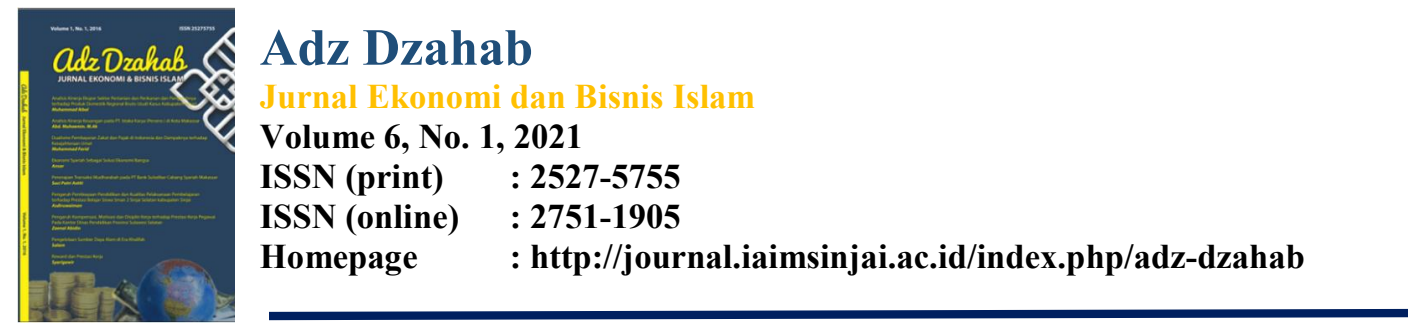

Selain kompensasi langsung, kompensasi tak langsung juga mempunyai peranan yang tak kalah pentingnya untuk meningkatkan kinerja guru. Guru sangat membutuhkan kompensasi tidak langsung ini karena dapat mengurangi stres dan meningkatkan motifasi bekerja. Bisa jadi kompensasi gaji yang diberikan oleh sekolah tidak terlalu kompetitif dibandingkan dengan yang di tawarkan oleh sekolah lain, tetapi dengan di lengkapi pemberian berbagai kompensasi tidak langsung ini dapat menarik minat guru untuk selalu setia mengabdi di sekolah tersebutAdapun bentuk-bentuk kompensasi tidak langsung adalah:

a. Tunjangan

Pada umumnya tunjangan diberikan sebagai tambahan gaji atau upah yang berfungsi untuk mensejahterakan pegawai.

\section{b. Asuransi}

Asuransi merupakan penanggulangan risiko atas kerugian, kehilangan manfaat dan tanggung jawab hukum kepada pihak ketiga yang timbul dari dari peristiwa yang tidak pasti. Dengan adanya asuransi, seseorang guru khususnya tenaga kerja honorer tidak perlu akan khawatir tentang kejadian-kejadian tidak terduga dimasa depan.

B. Faktor faktor yang mempengaruhi kompensasi.

Faktor-faktor yang berpengaruh terhadap kompensasi yaitu faktor internal organisasi dan faktor eksternal organisasi. Faktor internal organisasi seperti ketersediaan dana organisasiyang umumnya. Jika dalam perusahaan faktor interna ini berasa dari keuntungan yang didapat organisas, sedangkan pada organisasi pendidikan, faktor interna ini berupa dana operasiona yang berasal baik dari pemerintah maupun dari pemerintah maupun dari siswa atau orang tua siswa. Kebijakan dalam menentukan besarnya kompensasi dipengaruhi oleh besar kecilnya organisasi. Semakin besar organisasinya dan semakin kuat manajemennya akan memberikan jaminan gaji sesuai kemampuannya yang lebih besar, terstruktur, dan kompetitif. Begitu juga faktor pribadi pegawai, seperti produktifitas kerja, posisi dan jabatan, pendidikan dan pengalaman, jenis, dan sifat pekerjaan, akan menentukan penawaran gaji yang diberikan.

Sedangkan faktor eksternal organisasi yang berpengaruh terhadap gaji antara lain penawaran dan permintaan kerja. Jika mengacuh pada hukum ekonomi pasar bebas, kondisi dimana penawaran (supply) tenaga kerja lebih dari penerimaan (deman), maka akan menyebabkan rendahnya kompensasi yang diberikan. Begitu juga sebaliknya. Besar nilai kompensasi yang ditawarkan suatu organisasi merupakan daya tarik calon pengawai untuk memasuki organisasi itu. Faktor lain adalah standar biaya hidup. Besarnya kompensasi terutama gaji harus disesuaikan dengan besarnya biaya hidup (cost of living), yaitu biaya hidup minimal di suatu daerah. Faktor eksternal lain adalah kebijakan pemerintah dan kondisi perekonomian nasional. Sebagai pemegang kebijakan, pemerintah berupaya melindungi rakyatnya dari kesewenangan. Dalam hal ini pemerintah menetapkan. upah minimum, jam hari kerja per hari, kesetaraan pria dan wanita, batas umur kerja, dan sebagainya. Begiu juga kondisi perekonomian nasional. Semakin maju tingkat perekonomian suatu negara, maka semakin baik penghargaan terhadap sumberdaya manusianya. Ada tiga hal yang perlu mendapat perhatian untuk merancang, menetapkan dan mengefaluasi program kompensasi: 


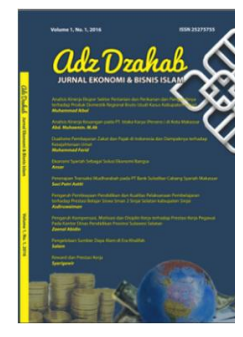

Adz Dzahab

Jurnal Ekonomi dan Bisnis Islam

Volume 6, No. 1, 2021

ISSN (print) : 2527-5755

ISSN (online) : 2751-1905

Homepage : http://journal.iaimsinjai.ac.id/index.php/adz-dzahab

1) Gaji umumnya merupakan faktor yang paling penting bagi pengawai dan sekurang-kurangnya akan mempunyai dampak terhadap pilihan pekerjaan, kepuasan kerja, kehadiran, putaran pegawai, dan dan produktifikas kerja.

2) Sistem ketenagakerjaan senantiasa berubah dengan cara-cara yang dapat diprediksi.

3) Sistem gaji harus disesuaikan dengan perubahan sistem, yaitu ketenagakerjaan, organisasional, hukum, serta kesempatan dan ancaman lingkungan lainnya.

Organisasi memiliki beberapa tujuan untuk merancang sistem kompensasi. Manajemen organisasi harus memikirkan tujuan sistem dan apa kebutuhan organisasi untuk mencapai tujuan itu. Sebuah sistem kompensasi haruslah untuk memikat dan mempertahankan para pengawai yang cakap, dapat memotifasi pegawai, mematuhi suatu peraturan hukum, menguntungkan operasional organisasi dan meredam kekacauan.

Terkait dengan kompensasi, dalam bidang pendidikan, hasil penelitian Kartowagira menunjukkan bahwa kinerja sebagian besar guru profesional, kemampuan guru profesional dalam menyusun RPP dan melaksanakan pembelajaran sudah baik. Berdasarkan penilaian kepala sekolah, kompensasi kepribadian dan sosial para guru yang sudah lulus sertifikasi dan telah menerima tunjangan profesi sangat baik. Upaya sebagai guru dalam membimbing siswa mengikuti lombah atau olimpiade sudah baik.

Usaha sebagian besar guru yang telah lulus sertifikasi dan telah menerima tunjangan profesi dan membuat modul dan membuat media pembalajaran baik Berbagai faktor yang mempengaruhi tingkat kompensasi, yaitu:

1) Penawaran dan permintaan tenaga kerja

Meskipun hukum ekonomi tidak bisa digunakan mutlak dalam tenaga kerja, tetapi tidak bisa di ingkari bahwa hukum penawaran dan permintaan tetap mempengaruhi untuk pekerjaan yang membutuhkan keterampilan tinggi, dan jumlah tenaga kerjanya langkah. Maka upah akan cenderung tinggi sedangkan untuk jabatan-jabatan yang mempunyai penawaran yang melimpah upah cenderung menurun.

2) Organisasi buruh

Ada tidaknya organisasi buruh, serta kuat tidaknya organisasi buru akan turun mempengaruhi tingkat kompensasi. Adanya serikat buru yang kuat, yang berarti posisi "bargaining" karyawan juga kuat. Sehingga akan menaikan tingkat kompensasi, demikian juga sebaliknya.

3) Kemampuan untuk membayar

Meskipun karyawan dalam hal ini serikat buru menuntut tingkat kompensasi yang tinggi, tetapi realisasi pemberian kompensasi akan tergantung pada kemampuan bayar dari perusaan, maka jelas perusahaan akan tidak mampu memenuhi fasilitas karyawan.

4) Produktifitas

Kompensasi sebenarnya merupakan imbalan atas prestasi karyawan. Semakin tinggi prestasi karyawan seharusnya semakin besar juga kompensasi yang akan diterima karyawan tersebut.

5) Biaya hidup 


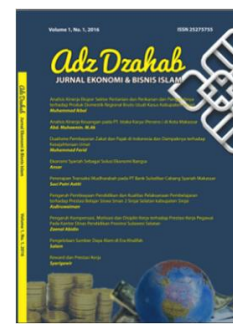

Adz Dzahab

Jurnal Ekonomi dan Bisnis Islam

Volume 6, No. 1, 2021

ISSN (print) : 2527-5755

ISSN (online) : 2751-1905

Homepage : : http://journal.iaimsinjai.ac.id/index.php/adz-dzahab

Faktor yang mempengaruhi tingkat kompensasi adalah biaya hidup. Di kota-kota besar dimana biaya hidup tinggi, akan menjadikan tingkat kompensasi yang tinggi.

6) Pemerintah

Pemerintah dengan peraturan-peraturan juga mempengaruhi tinggi rendahnya kompensasi

C. Tujuan Pemberian Kompensasi

Pemberian kompensasi bertujuan sebagai berikut:

1) Pemenuhan kebutuhan. Karyawan menerima kompensasi berupa upah, gaji atau bentuk lainnya adalah untuk dapat memenuhi kebutuhan hidupnya sehari-hari atau dengan kata lain, kebutuhan ekonominya. Dengan adanya kepastian menerima upah atau gaji tersebut secara periodik, bararti adanya jaminan "economic security" bagi dirinya dan keluarganya yang menjadi tanggunganya.

2) Meningkatkan produktifitas kerja. Pemberian kompensasi yang semakin baik akan mendorong karyawan bekerja secara produktif.

3) Memajukan organisasi atau perusahaan. Semakin berani suatu perusahaan atau organisasi membarikan kompensasi yang tinggi, semakin menunjukkan betapa makin suksesnya suatu perusahaan sebab pemberian kompensasi yang tinggi hanya mungkin apabila pendapatan perusahaan yang digunakan untuk itu makin besar.

4) Menciptakan keseimbangan dan keadilan. Ini berarti pemberian kompensasi berhubungan dengan persyaratan yang harus dipenuhi oleh karyawan pada jabatan sehingga tercipta keseimbangan antara "input" (syarat-syarat) dan "output".

D. Menentukan Kompensasi

Banyak faktor yang ikut menentukan berapa besar kompensasi yang harus diberikan kepada pengawainya. Dalam sistem organisasinya pendidikan, kompensasi termasuk dalam pembiayaan pendidkan. Pembiayaan pendidikan ini merupakan bagian dari rencana anggaran dan kegiatan pendidikan. Perencanaan anggaran dan kegiatan pendidikan perencanaan anggaran dan kegiatan pendidikan ditentukan seberapa besar angaran yang disediakan untuk pendidikan. Untuk menentukan besarnya kompensasi menjadi dasar pertimbangan:

1) Anggaran pendidikan oleh pemerintah

Pada sekolah (terutama yang kelolah oleh pemerintah), besarnya anggaran ditentukan oleh kemampuan masyarakat dalam membayar pajak dalam bentuk APBN dan APBD. Pemerintah dengan persetujuan dengan (DPR) dapat menentukan berapa besar anggaran APBN dan APBD yang disediakan untuk pendidikan. Semakin tinggi APBN dan APBD, semakin besar pula anggaran untuk pendidikan, dan semakin tinggi pula mata anggaran yang disediakan untuk. kompensasi atau gaji dan belanja pegawai. Misalnya di negara kita Indonesia, pemerintah membuat kebijakan bahwa anggaran untuk pendidikan dialokasikan sebanyak 20\% dari APBN dan APBD. Dari jumlah anggaran yang menyerap 20\% APBN dan APBD itu, 50$70 \%$ di dalamnya dialokasikan untuk gaji dan kesejahteraan pegawai. Sebagai tindak lanjut dari kebijakan itu, maka pemerintah secara berkala selalu menaikkan gaji guru/pendidik dan tenaga kependidikan. Disamping itu, kompensasi- kompensasi yang lain juga mendapat perhatian. Misalnya 


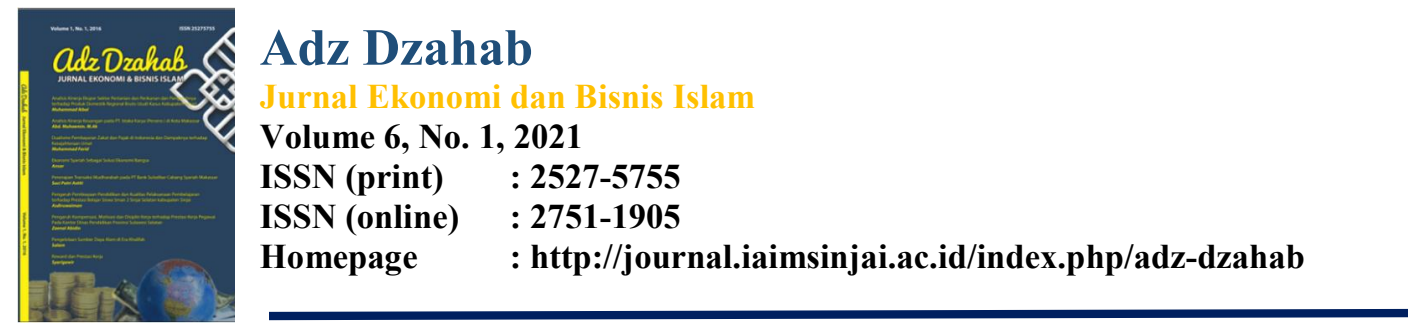

kesejahteraan dalam bentuk tunjangan profsi, perbaikan peralatan dan fafilitas pembelajaran, dan yang lainnya dapat direalisasikan.

2). Anggaran pendidikan disediakan oleh masyarakat.

Pada sekolah swasta dengan pengelolaan oleh yayasan, ia mengangkat pegawai (pendidik dan tenaga kependidikan) sebagai pegawai tetap yayasan. Besarnya kompensasi bagi pegawai tetap ini di tentukan oleh kemampuan yayasan. Kemampuan yayasan dalam menyediakan. anggaran untuk pendidikan biasanya tampak dari besar kecilnya yayasan penyandang dana. Yayasan yang memiliki penyandang dana besar umumnya memberikan kompensasi pegawai secara memadai. Sebaliknya, yayasan yang tidak memiliki penyandang dana besar dan kuat kurang/tidak mampu memberikan kompensasi yang memadai kepada para pegawainya. Namun demikian, karena pendidik (utamanya guru) sudah di undang-undangkan sebagai profesi, maka pemberian kompensasi harus dilakukan sesuai persyaratan suatu profesi. Salah satu syarat profesi adalah memberikan gaji yang layak sebagai nafka utama bagi anggota profesi. Layak dalam hal ini mengandung makna bahwa gaji tersebut bisa bisa digunakan untuk memenuhi kebutuhan pokok hidup berstandar di suati daerah. Untuk itu, di tentukanlah standar pembayaran regional dalam bentuk batas Upah Minimal Regional (UMR). Kompensasi (utamanya gaji) yang diterima oleh pegawai dalam suatu profesi seharusnya tidak kurang dari UMR. Dengan demikian, para pengawai dapat hidup layak disuatu daerah. Setiap daerah mungkin membutuhkan standar minimal kehidupan yang berbeda dengan daerah lain.

4) Standar pembayaran sesuai kontrak

Besarnya kompensasi jika ditentuka melalui proses tawar-menawar kolektif yang kemudian mendapat persetujuan dalam kontrak. Tawarmenawar kolektif dapat dilakukan secara informal dan formal. Walaupun beberapa sekolah berada dalam geografis yang sama, sulit ditemukan standar gaji yang sama karena perbedaan kekayaan, sikap publik, status sekolah, dan tekanan-tekanan yang lain. Untuk itu, perlu dilakukan negosiasi antara sekolah dengan pelamar sebelum kontrak ditandatangani. Hal lain yang berkaitan dengan kontrak adalah lamanya kontrak. Lamanya kontrak ditentukan oleh dewan dan yayasan pendidikan, apakah menetapkan kontrak jangka pendek dengan durasi dua sampai tiga tahun, atau kontrak jangka panjang sampai batas usia pensiun. Lamanya persetujuan kontak dipengaruhi oleh tingkat inflasi saat ini dan yang akan datang. Ketika inflasi menurun, gaji meningkat pada tingkat yang lebih tinggi dari tingkat inflasi. Pada pegawai yang baru, mungkin menerima hal ini, namun bagi pegawai yang ingin agar mereka memiliki gaji pada tingkat yang paling tinggi sebelum masa pensiun, mereka akan merasa bahwa kompensasinya lebih rendah dari pada inflasi

5) Perbandingan gajiPerbandingan gaji merupakan suatu hal yang harus dibuat karena perbandingan gaji antara suatu daerah dengan daerah lain, antara sekolah yang satu dengan sekolah yang lain akan memberikan informasi yang dapat digunakan untuk mengestimasi biaya agar mencapai gaji yang kompetitif. Dalam kaitan dengan ini, seseorang manajer personalia atau negosiator perlu menentukan bagaimana memperoleh sebuah kesepakatan yang akan menempatkan pengawai 


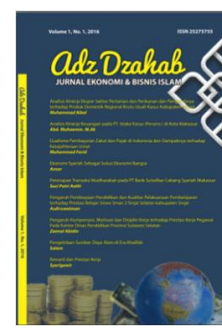

Adz Dzahab

Jurnal Ekonomi dan Bisnis Islam

Volume 6, No. 1, 2021

ISSN (print) : 2527-5755

ISSN (online) : 2751-1905

Homepage : http://journal.iaimsinjai.ac.id/index.php/adz-dzahab

dalam wilayah gaji yang kompetitif, namun tetap dipercaya sebagai sesuatu yang adil.

6) Membaca skala gaji

Gaji pegawai hendaknya dibayarkan dalam bentuk daftar skala gaji. Hal yang perlu diperhatikan dalam membaca skala gaji adalahrentang awal gaji yang aktual, jumlah golongan/pangkat, jumlah dana dalam setiap golongan, jumlah personal dalam setiap golongan. Dalam daftar skala gaji harus tertulis secara jelas yang membedakan kompenen gaji dan bentuk- bnetuk kompensasi yang lain. Pada kompenen gaji, pada terbaca skala dan rentang gaji, mulai awal sampai gaji yang dibayarkan terakhir. Pada skala gaji terlihat berada gaji pokok, berapa kenaikan berkala, dan seterusnya. Begitu juga kompensasi lain hendaknya tertulis jelas jenis, keterangan dan jumlahnya. Dengan demikian, pegawai penerima gaji dapat membandingkan uraian dan rincian gaji yang tertera pada skala gaji dengan gaji rill yang diterima. Dengan skala gaji itu pula, pegawai penerima gaji dapat membandingkan secara kompetitif dengan gaji yang diterima oleh pegawai.

7) Pembayaran tambahan

Pembayaran tambahan selalu dikaitkan dengan bidang kerja, lamanya kerja disekolah yang bersangkutan, dan tambahan jam atau hari kerja. Ada banyak jenis pembayaran tambahan yang didasarkan atas banyak hal antara lain:

a. Pembayaran tunjangan profesi guru yang sudah bersertifikat pendidik.

b. Pembayaran tambahan bagi guru yang memiliki kualifikasi di atas yang dipersyaratkan. Misalnya pembayaran tambahan bagi guru yang bergelar master dan doktor.

c. Pembayaran tambahan atas lamanya dalam goglongan ai atas posisi daftar gaji.

d. Pembayaran tambahan bagi guru yang mendapatkan jaminan khusus antara prestasi tertentu.

e. Pembayaran tambahan bagi guru yang telah berpengalaman.

f. Pembayaran tambahan atas perannya sebagai koordinator pada kegiatan (tugas tambahan).

g. Pembayaran prestasi. Pembayaran prestasi perlu didiskusikan dan mendapatkan pemahaman yang sama. Yang dimaksud prestasi bagi guru tidak semata-mata diukur pada prestasi langsung bagi guru, tetapi juga prestasi yang dihasilkan oleh siswanya. Dengan demikian, prestasi dapat dipahami sebagai pembelajaran yang efektif. Faktor lain yang juga dipertimbangkan dalam pembayaran prestasi antara lain kehadiran, kerelaan melaksanakan tugas pembelajaran yang sulit, mengikuti pelatihan untuk meningkatkan kemampuan profesional, kerja sama untuk memenuhi target sekolah dalam satu wilayah, dan sebagainya. Pembayaran prestasi hendaknya diperuntukkan bagi semua pegawai, sehingga mereka memperlihatkan prestasi di atas rata-rata. Cara memberikan pembayaran prestasi dapat dilakukan dengan pemberi bobot tingkat prestasi yang dicapai oleh setiap pegawai yang dituangkan dalam instrumen evaluasi. 


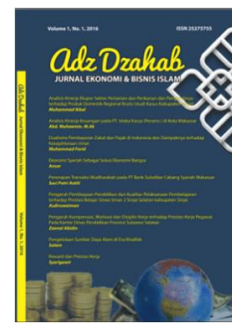

Adz Dzahab

Jurnal Ekonomi dan Bisnis Islam

Volume 6, No. 1, 2021

ISSN (print) : 2527-5755

ISSN (online) : 2751-1905

Homepage : http://journal.iaimsinjai.ac.id/index.php/adz-dzahab

h. Yang tidak termasuk dalam persetujuan pembayaran. Ada beberapa hal yang tidak termasuk dalam persetujuan pembayaran kompensasi. Pegawai perlu mendapat kejelasan informasi hal- hal yang tidak termasuk dalam perhitungan kompensasi. misalnya kehadiran/ketidakhadiran pendefinisian peran (seperti ketua dan anggota), jam kerja, jadwal libur, sakit, perjalanan, liburan, dan sebagainya. Kejelasan mengenai hal-hal tersebut perlu dibuat dalam kebijakan pembayaran kompensasi, sehingga pegawai memahami secara penuh dan memutuskan untuk menerima kompensasi atau menolaknya. Jika kompensasi tidak memasukkan hal-hal tersebut dalam negosiasi pembayaran, maka perlu dibuat kebijakan pendidikan yang mencukupi skala gaji jika terjadi hal-hal yang tidak diatur dalam pembayaran kompensasi.

E. Konsep Kinerja

Kinerja merupakan suatu kegiatan yang diakukan untuk meaksanakan, menyelesaikan tugas dan tanggung jawab sesuai dengan harapan dan tujuan yang teah ditetapkan. Kinerja diartikan sebagai prestasi, menunjukkan suatu kegiatan atau perbuatan dan meaksanakan tugas yang telah dibebankan. Pengertian kinerja sering diidentikkan dengan prestasi kerja. Kinerja mengandung makna hasi kerja, maupun prestasiatau dorongan untuk melaksanakan suatu pekerjaan. Kinerja pada dasarnya adalah sebuah proses dalam manajemen sumber daya manusia.16Keberhasilan individu atau organisasi dalam mencapai target atau sasaran tersebut merupakan kinerja. Dapat disimpulkan bahwa kinerja adalah hasil kerja yang telah dicapai oleh seseorang dalam suatu organisasi untuk mencapai tujuan berdasarkan atas standardisasi atau ukuran dan waktu yang disesuaikan dengan jenis pekerjaannya dan sesuai dengan norma dan etika yang telah ditetapkan.

F. Kinerja Guru

Kenerja guru sangat penting dalam proses pembelajaran, dengan melaksanakan tugas mengajar maka proses pembelajaran akan terwujud. Pengertian kinerja guru Kinerja guru merupakan kemampuan seorang guru dalam melaksanakan tugas pembelajaran dan bertanggung jawab atas peserta didik di bawah bimbingannya dengan meningkatkan prestasi belajar peserta didik. Oleh karena itu, kinerja guru itu dapat di artikan sebagai suatu kondisi yang mejunjukkan kemampuan seorang guru dalam menjalankan tugasnya serta menggambarkan adanya suatu perbuatan tang ditampilkan guru dalam atau selama melakukan aktivitas pembelajaran. Kinerja guru tdak hanya ditunjukkan oleh hasil kerja, akan tetapi juga ditunjukkan oleh perilaku dalam bekerja. Lembaga Administrasi Negara menyebut kinerja sebagai: "gambaran tentang tingkat pencapaian pelaksanaan suatu kegiatan dalam mewujudkan sasaran, dengandemikian, kinerja guru secara langsungmengacuh kepada perwujudan keadaan tingkat perilaku guru dengan sejumlah persyaratan. Kenerja seseorang, kelompok atau organisasi tidak sama, satu dengan yang lain tergantung dengan tugas dan tanggung jawab secara profesional. Dengan demikian, guru berhubungan dengan peran sebagai pelatih yang akan memfasilitasi seluruh aktivitas organisasi. Kinerja guru juga dapat ditunjukkan dari seberapa besar kompetensi-kompetensi yang dipersyaratkan dipenuhi, kinerja guru dapat terlihat jelas dalam pembelajaran yang diperlihatkannya dari prestasi belajar peserta didik yang baik. Adapun kriteria yang dapat dipergunakan untuk mengukur kinerja adalah: 


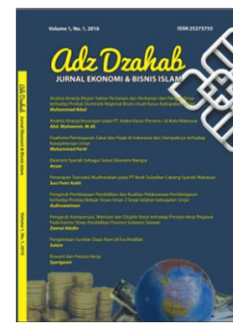

Adz Dzahab

Jurnal Ekonomi dan Bisnis Islam

Volume 6, No. 1, 2021

ISSN (print) : 2527-5755

ISSN (online) : 2751-1905

Homepage : http://journal.iaimsinjai.ac.id/index.php/adz-dzahab

1. Kualitas

Tingkat dimana hasil aktivitas yang dilakukan mendekati sempurna dalam menyesuaikan beberapa cara ideal dari penampilan aktivitas ataupun memenuhi tujuan-tujuan yang diharapkan dari suatu aktivitas.

2. Kuantitas

Jumlah yang dihasilkan dinyatakan dalam istilah-istillah seperti dolar, jumlah unit, jumlah siklus aktivitas yang diselesaikan.

3. Ketepatan waktu

Tingkat suatu aktivitas diselesaikan pada waktu awal yang diinginkan, dilihat dari sudut koordinasi dengan hasil output serta memaksiakan waktu yang tersedia untuk aktivitas lain.

4. Efektivitas

Tingkat penggunaan sumber daya organisasi (tenaga, uang, teknologi, bahan baku) dimaksimalkan dengan menaikkan keuntungan atau mengurangi kerugian dan setiap unit atau instansi dalam penggunaan sumber daya.

5. Komitmen kerja

Kriteria ini berhubungan dengan tingkat komitmen yang diimiki oleh pengawai dalam melaksanakan tugas dan tanggung jawabnya.Aspek kualitas pembelajaran merupakan upaya- upaya guru untuk. menyampaikan pembelajaran supaya mudah dipahami, mudah diingat dan menyenangkan. Guru perlu menyampaikan materi pembelajaran secara tersusun dan sistematik; menggunakan bahasa yang jelas dan mudah; memberi informasi yang jelas serta memberi contoh-contoh yang saling berkaitan; memberi penekanan kepada materi esensial dan mengaitkan pelajaran itu engan pengetahuan dan pengalaman peserta didik yang telah dimiliki peserta didik dan menggunakan alat bantu pembelajaran bagi membantu menjelaskan sesuatu konsep. Selain itu, tujuan pelajaran juga hendaklah jelas dan dapat diatur serta isi kandungan pembelajarannya mencakup juga penilaian yang perlu diadakan pada kegiatan akhir pembelajaran.Profesi guru merupakan bidang pekerjaan khusus yang dilaksanakan berdasarkan prinsip-prinsip:

a) Memiliki bakat, minat, panggilan jiwa dan idealisme

b) memiliki komitmen untuk meningkatkan mutu pendidikan, keimanan, ketakwaan, dan akhlak mulia;

c) memiliki kompetensi yang diperlukan sesuai dengan bidang tugas;

d) memperoleh penghasilan yang ditentukan sesuai dengan prestasi kerja;

e) memiliki kesempatan untuk mengembangkan profesionalan secara berkelanjutan.

f) memiliki jaminan perlindungan hukum dalam melaksanakan tugas keprofesionalan.

g) memiliki organisasi yang mempunyai kewenangan mengatur hal-hal yang berkaitan dengan tugas keprofesionalan guru.

Berdasarkan hasil analisis regresi sederhana yang telah dilakukan, pada tabel coefficients diketahui t-hitung kompensasi 4,072>2,364(t tabel) jadi $\mathrm{H}_{a}$ diterima dan $\mathrm{H}_{0}$ ditolak, maka dapat dikatakan bahwa kompensasi berpengaruh terhadap kinerja guru honorer di SD Negeri 30 Tongke-Tongke Kab. Sinjai. 


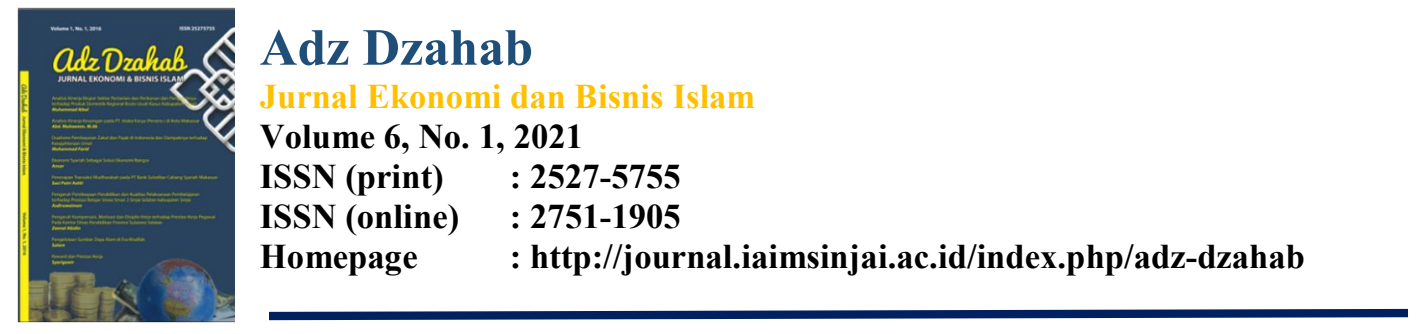

Sedangkan pada nilai probablitas $0,005<0,05$, maka kompensasi berpengaruh terhadap kinerja guru honorer di SD Negeri 30 Tongke-Tongke Kab. Sinjai. Untuk mengetahui besar kontribusi antara kompensasi terhadap kinerja guru dapat dilihat pada tabel model summary dengan melihat R Square=0,703atau 70,3\% jadi besar pengaruh kompensasi terhadap kinerja guru honorer di SD Negeri 30 Tongke-Tongke Kab. Sinjai adalah 70,3 \% dengan kata lain terdapat aspek- aspek selebihnya yang memiliki pengaruh terhadap kinerja guru honorer di SD Negeri 30 Tongke-Tongke Kab. Sinjai. Dari kedua pengujian hasil penelitian menunjukkan bahwa kompensasi memiliki pengaruh positif dan signifikan dengan kinerja guru honorer SD Negeri 30 Tongke-Tongke Kab. Sinjai

\section{Simpulan}

Kompensasi memiliki pengaruh positif dan signifikan $\mathrm{t} e \mathrm{r} \mathrm{h}$ a d a $\mathrm{p}$ kinerja guru honorer SD Negeri 30 Tongke- Tongke Kab. Sinjai. Hal ini diperoleh berdasarkan hasil analisis dengan menggunakan SPSS pada tabel coefficients diketahui t-hitung kompensasi4,072>2,364 (t tabel) dan nilai probabilitas $0,005 \quad 0,05$ dan pada tabel model summery dengan melihatR Square $=0,703$ atau $70,3 \%$. Jadi besar pengaruh kompensasi terhadap kinerja guru honorer SD Negeri 30 Tongke-Tongke Kab. Sinjai adalah 70,3\%. . Diharapkan pihak sekolah maupun dinas pendidikan sesalu fokus pada kompensasi, karena kompensasi berpengaruh terhadap kinerja guru honorer.

\section{Daftar Pustaka}

Achmad S.Ruky, Sistem Manajemen Kinerja, Cet. IV; Jakarta: PT Gramedia Pustaka Utama, 2006

Amos Nemos Neolaka.\& Grace Amalia Neolaka, Landasan Pendidikan Dasar

Dessy Prihatining Rahaynti Susilo Utami, Fakutas Psikologi Universitas Muhammadiyah Surakarta, 2010.

Djumhur. Bimbingan dan penyuluhan disekolah. Bandung: CV.Ilmu. 1975.Mengenal Diri Sendiri Menuju Perubahan Hidup, Cet. I; oktober 2017.

Firdus, et.al., Pedoman Penulisan Skripsi Institut Agama Islam Muhammadiyah Sinjai, Cet II, CV. Latinulu, 2018.

Jamil suprihatiningrum, guru profesional, cet III, yogjakarta: Ar-Ruzz Media, 2016.

Kang Ismet\&CB Blogger,pengaruh kompensasi terhadap kinerja karyawan pada asuransi jiwa bersama (ajb) bumiputera 1912 cabang pasuruan kota, diakses tanggal 07 Desember 2018, dari http://www.pekerjadat a.com/2014/04/40-skripsi-pengaruh-kompensasi- terhadap.html, 28 juni 2015.

Kartowagiran, Kinerga Guru Profesional (Guru Pasca Sertifikasi).Cakrawala Pendidikan Jurnal Ilmia Pendidikan. XXX (3). h. 130.

Nurul Ulfatin \& Teguh Triwiyanto, manajemen sumber Daya Manusia, Cet. I; Jakarta: PT Raja Grafindo Persada, 2016.

Rosady Ruslan. Metode penelitian public Relations dan komunikasi,jakarta:Rajawali pers, 2013

Supardi, Kinerja Guru,cet. 1;Jakarta PT Raja Grafindo Persada, 2013.

Suharsimi Arikunto, ProsedurPeneitian: suatu pendekatan praktik, Cet. XIII;JAKARTA: PT Rineka Cipta, 2006.

Suharsimi Arikunto, ProsedurPeneitian: suatu pendekatan praktik, Cet. XIII;JAKARTA: PT Rineka Cipta, 2006.

Setyo Tri Wahyudi, Statistika Ekonomi,Cet. I; Malang: UB Press, 2017.

Yani, manajemen sumber daya manusia, cet, jakarta: mitra wacana media, 2012.

Yoyo Sudaryo, et.al., Manajemen Sumber daya Manusia, Yogyakarta: Andi 2018 